....a joint resource which remains intact as an unbroken natural system, despite the long presence of political boundaries.'

Within the accompanying documentation both Governments note:

'Over 14,000 Dall's Sheep [Ovis canadensis s.1.], the single largest group in the world, are found on lands encompassed by the nomination.

Proposed amendments to ANILCA would open a stretch of $113 \mathrm{~km}$ of land, encompassing an area of more than 650,000 ha along the Canada-USA border, to sport hunting. Therefore a significant portion of the World Heritage Site in Alaska would be subject to sport hunting.

Dall's Sheep migrate back and forth across the Alaska-Yukon boundary, hence the legitimate Canadian concern about proposed revision of ANILCA. This situation was not contemplated in the 1979 nominationnor, presumably, was it envisaged by those who adjudicated the application. However, removing much of the land within Wrangell-Mt St Elias National Park from management under National Parks legislation raises the question of international obligations assumed by states when administering World Heritage Sites and, in this case, a specific obligation to the Government of Canada as a joint nominee of the site.
It is to be hoped that the international recognition and status which has been accorded the Site will restrain efforts to disestablish large portions of Wrangell-Mt St Elias National Park. Should the proposed amendment be passed, we may wonder how many other World Heritage Sites could suffer a similar fate to this first jointlynominated one!

\section{REFERENCES}

Cahn, R. (1982). The Fight to Save Wild Alaska. National Audubon Society, Washington, DC, USA: 32 pp., illustr.

FENGE, T. (1982). Towards comprehensive conservation of environmentally significant areas in the Northwest Territories of Canada. Environmental Conservation, 9(4), pp. 305-13, map.

WAYBURN, E. (1983). Hunters take aim at Alaska's National Parks: S49 and HR1493. Sierra, 68(3), pp. 16-9.

Terry Fenge, Director of Policy Studies Canadian Arctic Resources Committee 46 Elgin Street, Room 11

Ottawa

Ontario K1P $5 K 6$

Canada.

\title{
Australian High-court Decision Ensures Preservation of the South-West Tasmanian Wilderness
}

On 1 July 1983 the High Court of Australia handed down a decision which had the effect of causing construction work on a hydroelectric dam on the lower Gordon and Franklin Rivers in South-West Tasmania to be abandoned. The action by the High Court appears to be the final move to preserve the South-West Wilderness area of Tasmania, after a public debate which has been long-drawn-out, sometimes tangential, and widely acrimonious. ${ }^{*}$ The nature of the High Court case also appears to provide substantial legal precedent for greater involvement of the Federal Government in future environmental conservation issues in Australia.

By a 4 to 3 majority the Court upheld the constitutional validity of the World Heritage Properties Conservation Act, passed by the Australian Federal Parliament in May 1983. This Act was the means chosen by the Australian Labour Party government, led by Mr Robert Hawke, to meet the commitment to halt the Gordon-Franklin project which it had made during the election campaign three months earlier, and in which it gained office. The Act gave the Federal Government powers to prevent actions that would damage any properties in Australia which have been included on the World Heritage List. The nomination of substantial parts of the wilderness area of South-West Tasmania for inclusion on the World Heritage List was accepted in December 1982. The Federal Government argues that following the listing it was obliged, as a result of its adherence to the World Heritage Convention, to take action to protect listed areas.

The intent of the World Heritage Properties Conservation Act is to require that any action that damages

\footnotetext{
* See Dr Andrew K. Dragun's account of 'Hydroelectric Development and Wilderness Conflict in South-West Tasmania', published in our latest issue (Environmental Conservation, 10(3), pp. 197-204, 6 figs, Autumn 1983), and other items in recent issues.-Ed.
}

a property, the protection or conservation of which is a matter of international obligation on the part of Australia - whether by reason of the World Heritage Convention or otherwise - may only be undertaken with the consent of the Federal Government. This requirement is to apply to all Australian persons and organizations in Australia, including state governments and their agents. The body responsible for building the lower Gordon dam, the Hydro-Electric Commission of Tasmania, is a whollyowned agency of the Tasmanian State Government.

Prior to passage to the Act, the Federal Government sought to halt construction of the dam by means of regulations made under an existing piece of legislation, the National Parks and Wildlife Conservation Act. It went to the High Court for an injunction that the Tasmanian State Goverment comply with these regulations, while Tasmania made a counter-claim that the regulations were constitutionally invalid. Hearing of the matter did not start before passage of the new Act, and it was then agreed by discussion between the parties that the case should address the constitutional validity of the new Act. In essence Tasmania contended that the Act was unconstitutional and a violation of state rights, which traditionally have included matters pertaining to the environment.

The case was heard by the Full Bench of seven judges of the High Court during May and June 1983. The parties were in substantial dispute over environmental and economic implications of the hydroelectric scheme, and submitted considerable evidenciary material in support of their respective positions. However, the Court found that these disputed allegations did not affect the validity or otherwise of the Act, and made no judicial determination on them. In essence the High Court found that the Federal Government does have the power to enact legislation which might override state legislation on such matters as the environment, and that federal legislation is in line with international agreements and treaties which 
might have been entered into. The Court also found that the Hydro-Electric Commission of Tasmania is a trading corporation in the sense used in the Australian Constitution, and was thus subject to the power of the Federal Government.

Construction at the dam-site ceased following the announcement, and negotiations are currently under way between the Federal Government and Tasmanian State Government as to compensation to be paid in terms of lost employment and hydroelectricity production. The Federal Government has no legal obligation to pay compensation, but it made an election commitment to do so, and consequently it is generally accepted that both fairness and political expediency dictate that compensation be paid.

The decision of the High Court in this matter would appear to give the Federal Government powers to exercise similar jurisdiction over land-use and environmental decisions in the states when they relate to other international conventions on environmental mattersfor example those relating to migratory birds, endangered species, and wetlands. It also increases the Federal Government's autonomy to nominate further areas for inclusion on the World Heritage list. Until now the Federal Government has only nominated areas within states following a request to do so from the relevant state, and it was a request from a previous Tasmanian Government (which subsequently lost office in part because of its less-than-enthusiastic support for the Gordon dam) which resulted in the nomination of the South-West of the state as a World Heritage Site.

In future the Federal Government will be able to initiate the nomination process on its own, although it is expected that it would consult with the state government concerned. One area which it has been suggested might be nominated in this way is Fraser Island in the State of Queensland, that has been the subject of environmental conflict for many years.

\section{Hugh Saddler \& Andrew K. Dragun Centre for Resource and Environmental Studies Australian National University Post Office Box 4 Canberra ACT 2600 Australia.}

\section{The Biosphere as Seen by Students from Ann Arbor, Michigan}

We, graduate or graduating students at the University of Michigan, Ann Arbor, mainly from the College of Engineering, after having acquainted ourselves with the 'Declaration: The World Campaign for The Biosphere', have come to the following conclusions:

1. That The Biosphere, in addition to being a physical phenomenon and a biological one, as well as our lifesupporting system, is also a political phenomenon. It connects the boundaries of all nations, and its preservation is vital to the security and well-being of each and every nation and person on our Earth. In so far as there are some people and some interest-groups which intentionally or unintentionally damage The Biosphere, and threaten the well-being of nations, such people and groups are a threat to the world community. Therefore, an appropriate response must be found to their activities which, for lack of a better term, we call political-as it ultimately involves the body politic the world over.

In short, it is our conviction that we cannot deal with specific problems of The Biosphere, and be successful in preserving it, without at the same time considering the political implications and dimensions of the phenomenon of The Biosphere. By politics we do not mean petty interparty squabblings but a proper concern with the polis* which now embraces the entire globe, and which The Biosphere envelopes, shelters, and nourishes. In our opinion the politics of The Biosphere transcends partisan ideologies, for it is the politics of life.

2. That education is among the most important priorities in saving The Biosphere. This education should emphasize a variety of alternative perspectives concerning The Biosphere's systems. The educational programmes must stress the belief that meaningful solutions stem from value systems-including religious, ethical, and moral, convictions.

Educational policy agendas should incorporate direct communication of the agendas' goals to the following: grass-roots organizations, religious organizations, world

*A Greek city-state, especially when considered in its ideal form.-Ed. leaders, international committees, international corporations, and the news-transmission media. The realization of this educational goal would create improved understanding of the responsibilities and consequences of human occupance of The Biosphere.

3. That all the industries, and particularly large industries, in their efforts to maximize their benefit : cost ratio, make their primary objective the minimization of cost to the environment - namely that, in their analysis of the potential of any endeavour, the ecological, social, and human, consequences come before traditional costanalysis. A 'Biological Cost', implemented through international taxation on natural resources, will have to be included in the total cost-analysis.

4. That knowing how technology affects The Biosphere in manifold ways, and knowing also that we cannot anticipate all the consequences (as we do not fully understand all the relationships between new technologies and The Biosphere), very special care should be taken in the implementation of new technologies. First preference should be given to those technologies which are least harmful environmentally. The concept of preservation of The Biosphere must be inherent in the development of all new technologies. When a technology becomes inconsistent with this concept, the technologist must reexamine his or her involvement and be willing to discontinue participation in technologies whose primary purpose or application threatens The Biosphere.

5. That The Biosphere is ultimately a quasi-theological phenomenon. In order to treat it with due respect and take proper care of it, we must consider The Biosphere as sacred. Upholding The Biosphere as sacred, we acknowledge life as sacred-an assumption which all past cultures shared, and one that we surely wish to preserve.

Henryk Skolimowski, Professor (and the Seminar on Technology and Man) Department of Humanities University of Michigan

Ann Arbor

Michigan 48109

USA. 